\title{
Managing Price Risk in the Pakistan Wheat Market
}

\author{
Rashid Faruqee, Jonathan R. Coleman, and Tom Scott
}

\begin{abstract}
The government intervenes in the wheat market in Pakistan to ensure food security for consumers and to provide adequate and stable incomes for producers. The cost of this intervention is high, and its impact on the performance of agriculture has been significantly negative. The World Bank is urging policy changes such as removing agricultural trade restrictions, price supports, and subsidies. However, policymakers often resist such reforms, fearing that they will expose the domestic market to fluctuating international commodity prices.

This article assesses the risk management needs of the sector and evaluates whether using financial instruments-such as commodity bedging using futures, options, or swaps-would improve risk management. Simulations based on monthly data for 1994 show that market-based methods of risk management could reduce the impact of international price volatility on the domestic market without incurring high government cost or distorting price signals.
\end{abstract}

The Pakistan government has long intervened in the wheat sector because of its importance as Pakistan's leading agricultural commodity. Interventions in the sector seem to have two objectives-to protect the interests of consumers by keeping the domestic price below the import parity price and to protect the interests of producers by reducing price fluctuations and guaranteeing a support price. Foremost among the mechanisms used to meet the first objective, the government has set an import subsidy to keep domestic prices below import parity levels and has banned private sector trading on international markets. Although the government has succeeded in stabilizing wheat prices, the policy has had a significant economic cost in that it distorts the market signals facing farmers and private traders throughout the sector. The direct link between these signals and the volatile international price of wheat makes subsidy payments to wheat farmers both large and highly unstable.

Policymakers generally recognize the need to end the highly distortionary policy of keeping domestic wheat prices artificially low. However, they fear the possible short-run economic and political repercussions of agricultural price instability that would accompany the phasing out of public sector direct intervention in wheat marketing. They hesitate to implement market liberalization policies fully in the absence of alternative price stabilization mechanisms. (See Claessens

Rashid Faruqee and Jonathan R. Coleman are with the Agriculture and Natural Resources Division of the South Asia Region at the World Bank. Tom Scott is with Sparks Companies, Memphis, Tennessee. This research was funded by the World Bank's Research Support Budget (RPO 679-70).

Q 1997 The International Bank for Reconstruction and Development / THE WORLD BANK 
and Duncan 1993 and Gilbert 1993 on the stability of international commodity prices.)

Developing countries' interest in market-based risk management techniques, including the use of commodity futures, options, and swaps, has grown significantly in recent years. The use of such financial instruments could provide Pakistan with an attractive method of managing its price risk, as long as the mechanisms are understood well and used appropriately. Because they require less government intervention and are more cost-effective than alternative approaches, financial risk management instruments may be preferable to more interventionist stabilization methods in Pakistan.

This study deals with price risk of the wheat crop in Pakistan. It has two major objectives. First, it seeks to assess the risk management needs, if any, of the wheat sector by identifying the market participants and institutions exposed to risk and measuring the levels of those risks. Second, it seeks to evaluate whether market-based financial instruments would provide a less distortionary method of managing price risks than the stabilization methods currently used in the wheat sector.

This study adds to the growing body of research on how developing countries can hedge the risk associated with fluctuating agricultural commodity prices. The recent World Bank book by Claessens and Duncan (1993), Managing Commodity Price Risk in Developing Countries, contains eleven case studies. These case studies and others in the academic literature are fairly limited in their scope and coverage. They focus largely on exporting countries in Latin America and Africa. And they concentrate on a somewhat limited group of agricultural commodities, mainly cocoa, coffee, and cotton. See, for example, Myers (1993) and Claessens and Varangis (1993) on Costa Rican coffee exports; Satyanarayan, Thigpen, and Varangis (1993) on francophone African cotton exports; Varangis, Thigpen, and Akiyama (1993) on Egyptian cotton exports; and Claessens and Coleman (1993) on Papua New Guinea's gold, copper, coffee, cocoa, logs, and palm oil exports.

Few studies have been undertaken on hedging in the grain market. Larson (1993) examines the management of price risks for maize imports in Mexico. Much of Larson's paper concerns domestic price stabilization using variable border tariffs and subsidies to keep domestic prices within a price band. The study includes a discussion of how the government could use options to manage the risk of international price movements that would require subsidy payments to keep domestic prices within the price band. Sheales and Tomek (1987) examine the effectiveness of hedging wheat prices in Australia using U.S. futures markets. Faruqee and Coleman (1996) review these studies in more detail.

To date, very little work has been done from the perspective of a developingcountry importer wishing to hedge price risk in the world grain markets, and very few studies have looked at the prospects for commodity hedging in Asian countries. So, although this article focuses on hedging wheat in Pakistan, it has 
wider relevance to other Asian countries that rely heavily on grain imports to meet their food consumption needs.

\section{Wheat Price System and Incidence of Price Risks}

Determining the risk management needs of the wheat sector requires analyzing the various prices facing different market participants. Market participants facing prices fixed by the government have no price risk, whereas those facing highly unstable prices are likely to be the most interested in risk management.

\section{Prices and Subsidies}

The provincial food departments (PFDs) in Pakistan are the chief institutions through which the government implements its price support policy. The law requires PFDs to purchase any volume of wheat delivered to them as long as the wheat meets certain quality standards. The predetermined price paid to farmers is known as the procurement price. Because PFDs must accept all deliveries, the procurement price becomes a floor below which the free market price cannot fall. This price is fixed throughout the year and is constant across all centers nationwide. Provincial food departments sell the majority of their wheat to private flour mills at the release, or issue, price, which is set at the same level in all areas of the country. This policy aims to control the price of wheat at the wholesale level (although small differences between the release and wholesale prices do result from transportation margins and quality premiums), thereby reducing the price of flour to consumers (because wheat represents a large share of the total cost of producing flour).

The policy of artificially depressing prices is costly to the economy and the government. The price policy has a significant economic cost in that it distorts the market signals facing farmers and private traders throughout the sector (World Bank 1994). In particular, the system of pan-territorial pricing weakens private sector incentives for wheat transportation, while pan-seasonal pricing provides disincentives for private sector storage.

The system incurs subsidies, paid mainly by the provincial governments, because revenues received by the PFDs from the sale of wheat (at the release price) are generally less than the cost of procuring wheat (the procurement price plus transport, handling, and storage charges). Between 1984-85 and 1993-94, the average annual subsidy amounted to 340 rupees (PRs) per ton, approximately 18 percent of the procurement price. The total subsidy payments ranged from PRs533 million in 1984-85 to PRs3.3 billion in 1986-87 and averaged PRs1.3 billion over the 1984-93 period. ${ }^{1}$

The highest level of government decides the level of wheat imports. The Ministry of Agriculture implements the import of wheat and handles the financing of imports, including foreign aid and ocean shipping. The level of wheat imports depends on several factors, including the level of public sector stocks, the ex-

1. A billion is 1,000 million. 
pected procurement of domestic output, the handling capacity of ports, the level of reserve stocks, the conditions of the international wheat market, and foreign exchange reserves.

The PFDs buy imported wheat from the federal government at the same release price at which they sell domestically produced wheat to private millers. In addition, they pay the in-country transportation costs. In general, the government, buying at the CIF (the value including the cost, insurance, and freight) import price, pays more than it receives from selling to the PFDs at the release price. A specific federal budget allocation for imported wheat subsidies finances this margin between the CIF import price and the release price.

In 1993-94 this subsidy amounted to PRs590 per ton. Given total imports for 1993-94 of approximately 1.9 million tons, the government incurred a total subsidy payment of about PRs1.1 billion. This subsidy payment per ton has been quite variable over time, ranging between PRs341 per ton in 1987-88 and PRs1,660 per ton in 1989-90. Total subsidy payments have also fluctuated dramatically, as a result of both variations in the subsidy per ton and the level of imports. For example, the total subsidy payment was only PRs205 million in 1987-88 (when only 601,000 tons were imported), compared with PRs2.9 billion the next year (when imports exceeded 2 million tons).

Thus the government's intervention in the wheat market has two main objectives. It achieves the first objective, to reduce the average price paid by consumers vis-à-vis the import parity price, by setting the release price below the international price and making up the difference with a government subsidy. Over the period May 1980 to April 1995, the government subsidy was about PRs1,000 per ton. It achieves the second objective, to protect producers against the fluctuations of international commodity prices, by establishing a fixed procurement price below which domestic prices do not fall. Over the period May 1980 to April 1995, the coefficient of variation on the procurement price was about 6 percent, compared with 14 percent for the import parity price. This article focuses on the second objective of price stabilization. Although the government could adopt several methods of stabilizing prices, such as the use of buffer stocks or a buffer fund (see Faruqee and Coleman 1996, annex II), here we explore an alternative that involves hedging risk using financial instruments. Thus we compare the use of hedging only with the current method of stabilization, without looking at alternative methods.

\section{Incidence of Price Risk}

We measure the level of price risk facing different market participants by the standard deviation and coefficient of variation (the ratio of the standard deviation to the mean) of prices paid and received over time (a 16-year period between May 1980 and April 1995). Table 1 reports the domestic prices and results.

In terms of price exposure, the results show that domestic farmers and private traders face relatively little price risk. The government-determined prices have 


\begin{tabular}{lccc} 
Table 1. Measures of Price Variability in Pakistan, May & 1980-April 1995 \\
\hline Price per ton & Mean & $\begin{array}{c}\text { Standard } \\
\text { deviation }\end{array}$ & $\begin{array}{c}\text { Coefficient of } \\
\text { variation (percent) }\end{array}$ \\
\hline Procurement price (rupees) & 2,566 & 163.6 & 6.4 \\
Release price (rupees) & 2,645 & 154.2 & 5.8 \\
Wholesale price (rupees) & & & \\
$\quad$ Lahore & 3,044 & 254.6 & 8.4 \\
$\quad$ Multan & 2,809 & 222.4 & 7.9 \\
FOB Pacific Northwest (U.S. dollars) & 158.5 & 27.3 & 17.2 \\
CIF Karachi (U.S. dollars) & 187.6 & 38.6 & 20.6 \\
CIF Karachi (rupees) & 3,778 & 532.7 & 14.1 \\
FOB Pacific Northwest with EEP (U.S. dollars) & 154.3 & 31.6 & 20.5 \\
CIF Karachi with EEP (U.S. dollars) & 183.4 & 42.4 & 23.1 \\
CIF Karachi with EEP (rupees) & 3,687 & 614.6 & 16.7 \\
Government import subsidy (rupees) & 1,042 & 617.6 & 59.3 \\
\hline
\end{tabular}

Note: Prices are deflated by the producer price index. Lahore and Multan are cities in Pakistan. FOB denotes free on board (used to value exports); cIf denotes cost, insurance, and freight (used to value imports); and EEP denotes the U.S. government's Export Enhancement Program.

Source: Government of Pakistan (1995) and International Wheat Council (various issues).

coefficients of variation of 6.4 and 5.8 for the procurement price and release price, respectively (table 1). Wholesale wheat prices in the cities of Lahore and Multan have also varied very little since the early 1980 s, with coefficients of variation of about 8 percent.

By contrast, international prices have been substantially more volatile than domestic prices. The U.S. dollar price of wheat at Pacific Northwest ports has a coefficient of variation of 17.2 percent; when freight charges are included, the figure rises to 20.6 percent (table 1). Interestingly, when we use the Karachi U.S. dollar price to convert the price of wheat into rupees, the instability of the price series declines considerably with a coefficient of variation of only 14.1 percent. One explanation for this change is that although wheat prices and freight costs have declined in real terms over time, the value of the rupee in terms of the U.S. dollar has fallen. As a result, the decline in the commodity price has been offset by the change in the exchange rate, with the net effect that the international price in rupees has remained relatively stable.

The U.S. Export Enhancement Program (EEP) was introduced in 1985 to boost exports of U.S. agricultural products following their precipitous decline in the first half of the 1980s. The EEP pays subsidies to U.S. exporters to allow them to sell agricultural products in targeted countries at competitive prices (below U.S. market prices). The program helps U.S. products meet subsidized competition, expands U.S. agricultural exports, and encourages negotiations on agricultural trade problems. Wheat is the chief commodity sold under the EEP (accounting for more than 85 percent of the sales value of all EEP commodities), and EEP sales account for 50 percent of total U.S. wheat exports since 1985 . 
The EEP subsidies have increased the instability of wheat prices considerably, with the U.S. dollar prices at Pacific Northwest ports and at Karachi having coefficients of variation in excess of 20 percent (table 1). It is important to note that comparing the coefficients of variation of prices with and without EEP subsidies overestimates the impact of these export subsidies on variability, because the EEP subsidies lower the average price (the denominator in the coefficient of variation calculation), thereby giving rise to an increase in the coefficient of variation for a fixed standard deviation. Finally, we measure the government's price risk exposure by the variability of subsidy payments per ton (simplified as the CIF price measured in rupees less the release price). The coefficient of variation of this subsidy series is almost 60 percent, indicating that in a typical year subsidy payments will be 60 percent above or below the average payment. This indicates the high degree of instability and risk that the government faces each year.

These findings have several important implications for risk management. They indicate that the government has been successful in stabilizing prices through its procurement and policy of fixed producer and miller prices. Because of its distortionary impact on economic incentives and because there may be more effective and less costly methods of price stabilization, the policy may nevertheless be inadvisable. Another important implication for risk management is that given the current policy regime, farmers and millers have little incentive to manage risk on their own behalf. In effect, the government has crowded out private sector risk management, and farmers and millers have little need to worry about fluctuating prices when making production and investment decisions.

Price stabilization policies involving government procurement and pricing do not remove price risk from the economy as a whole but merely transfer the risk within the economy. The policies transfer the risk from wheat market participants in the form of unstable prices to the government (and ultimately to taxpayers) in the form of unstable subsidy payments.

\section{Price Stabilization, Hedging, and the Role of Government}

Under the existing system, the government stabilizes wheat prices for farmers and traders through its price and procurement policies. In the short term, such government intervention may be justified because market failures, such as the lack of available market information, unfamiliarity of farmers with risk management techniques, and absence of an effective system of brokerage, prevent market participants from engaging in price risk management through the private sector. In the long term, however, the government should stop its direct intervention and instead focus on providing economic and institutional conditions conducive to private sector risk management activities, including the establishment of futures exchanges in Pakistan.

There are several strong economic arguments against government intervention. For example, government stabilization of commodity markets generally 
constrains the active participation of the private sector, particularly in storage, transportation, and general trading activities. This is of great relevance to Pakistan, which has a system of pan-seasonal and pan-territorial pricing. This system has seriously weakened the economic incentives for private sector involvement in storage and transportation. Price stabilization also leads to welfare losses associated with the failure of producers and consumers to react to market signals (Massell 1969). For instance, if producers are insulated from the market through a government stabilization scheme, they will tend to overproduce in periods of lower international prices when domestic prices are artificially raised, and to underproduce in periods of high international prices when domestic prices are artificially lowered. Further, stabilizing prices does not stabilize income or profit. Instead, stabilizing prices with year to year fluctuations in production would result in greater income instability than if prices were allowed to adjust to the level of supplies (Thomas 1985). Stabilization schemes are difficult to implement, often requiring huge bureaucracies. They are also expensive (stabilization can be so expensive to operate that the costs of operating the program outweigh any benefits that might accrue to producers and consumers) and highly prone to political manipulation, as experience from many countries has shown (Knudsen and Nash 1990).

Although economic arguments generally do not support price stabilization by the government, considerable social and political pressures do. However, there may be ways to provide stabilization that are less distorting of economic incentives and that are more consistent with the market and trade liberalization reforms currently taking place in Pakistan.

Under the current system, the government pools the price risk of wheat farmers and traders and assumes it in the form of unstable subsidy payments. Having assumed the risk, however, the government can employ mechanisms with which to transfer the risk to entities willing and able to take it on. One way of transferring this risk would be to hedge the price of wheat with futures markets. Hedging involves the buying and selling of financial assets whose values are linked to the underlying commodity markets. Four major types of hedging instruments can be used-forward contracts, futures contracts, options, and swaps. Managing price risks through these mechanisms could be highly beneficial to Pakistan because doing so facilitates better financial management and planning and allows buyers and sellers of commodities to protect themselves against the potentially catastrophic consequences of sudden and unforeseen changes in market conditions.

In the long term, however, the government should phase out direct intervention (including public sector hedging activities) and confine itself to establishing economic conditions supportive of private sector hedging activities. The government should also provide the preconditions to set up commodity futures exchanges in Pakistan. (Several developing countries have established local futures and options exchanges. Examples include Argentina for grains and livestock; Brazil for livestock, coffee, cotton, and gold; China for various metals and agri- 
cultural commodities; Hungary for grains and hogs; India for pepper; Malaysia for palm oil, tin, and cocoa; the Philippines for copra, sugar, coffee, soybeans, and dry coconut; and Zimbabwe for corn and beans.)

For the private sector to engage in hedging activities using U.S. futures exchanges, the government should remove the obstacles that deter their use. Varangis (1994) identifies several such obstacles that are common in many developing countries, including Pakistan. First, legal and regulatory barriers prevent marketbased hedging. Foreign exchange controls, for example, which are common in many developing countries, can make hedging impossible. In terms of regulatory barriers, since the structural adjustment program in Pakistan was introduced, financial markets have become increasingly liberalized, and most foreign exchange controls have been lifted. In particular, there are no controls on transactions on the current account, including goods, services, and transfers. There are restrictions on the capital account; however, no current laws or statutes automatically prohibit hedging in commodities futures markets by Pakistani residents.

Second, the current system of fixing procurement and release prices for the whole season and announcing the prices well before planting means that private farmers and traders do not need to manage their own risk. Third, farmers and traders lack familiarity with futures markets and expertise in how to use them. In some developing countries the misconception that hedging is a form of speculation presents a major obstacle. Fourth, misunderstanding the tradeoffs between risks and returns can lead to the perception that hedging strategies that result in higher total import bills are counterproductive. Fifth, some hedging instruments require up-front costs that can represent obstacles for some potential market participants. Option contracts, for example, require a premium, futures contracts require a margin, and some forms of financial collateral may be required for swaps and over-the-counter arrangements.

Also in the long term, and as an alternative to hedging on U.S. exchanges, Pakistan could establish local exchanges. Varangis and Larson (1996) identify several preconditions for establishing futures exchanges in developing countries. These are highly relevant to setting up a wheat exchange in Pakistan, and an important future role of the government would be to ensure that such preconditions are met. These include the development of infrastructure in areas such as communications, transportation, and information processing; strong commercial and financial sectors; the absence of government intervention in the wheat market; a strong legal and regulatory framework in establishing a futures market; and sufficient capital among potential market participants to forestall counterparty risk (that is, sufficient capital to form a viable clearing entity). Although not insurmountable in the long term, such conditions are not likely to emerge in the short term.

Establishment of a wheat futures market would benefit Pakistan by improving price discovery and reducing basis risk. (The basis risk is the difference between the futures price in the United States and the market price in Pakistan.) A 
futures market would reduce the basis risk by specifying wheat contracts for the varieties and qualities of local wheat and for delivery within the country (in Lahore or Karachi, for example). Other benefits include more publicly available information on wheat prices, improved transmission of price and other commodity information, improved credit systems, more responsive capital markets, uniformity in repayment rules and market surveillance, reduced transactions costs, and more accurate forward prices (Varangis and Larson 1996).

In the next section, we compare these factors with the benefits and costs of using U.S. futures exchanges. U.S. exchanges have an advantage because they have well-established rules and regulations and are very liquid. Higher levels of liquidity mean reduced transactions costs that can outweigh the basis and exchange rate risks. The main disadvantage of using a U.S.-based exchange is that the basis risk and exchange rate risk can be large. Overall, however, the advantages outweigh the disadvantages, and Pakistan should use U.S. exchanges until it can set up viable domestic exchanges.

\section{Effectiveness of Hedging Wheat Price Risk}

Even with no legal and institutional barriers and no informational or awareness constraints, hedging still might not provide Pakistan with an effective means of managing its commodity price risk. The effectiveness of hedging depends on the nature of the commodity traded, the timing of purchases, land and ocean transportation charges, exchange rate movements, export subsidies, and other policy variables-factors that disassociate the prices quoted on the commodity exchanges with those actually paid by importers in Pakistan. All of these factors create a difference between the prices quoted on commodity exchanges and the prices actually paid by wheat importers. Greater unpredictability in the basis, or the difference between the two prices, reduces the effectiveness of managing risk by hedging.

By observing the basis over time, experienced hedgers are able to predict the basis with a good degree of accuracy. Unforeseen differences between the futures contracts and cash prices result in an unpredicted basis. This risk, the basis risk, cannot be managed by hedging. Because hedging does not eliminate all uncertainty, it can be viewed as merely substituting basis risk for price risk. Overall risk is nevertheless reduced because basis risk is considerably less than price risk (because cash and futures prices tend to be closely correlated).

Analysts commonly test for the correlation between cash prices of government wheat purchases on the international market and wheat futures prices by regressing a time series of nearby futures contract prices on the corresponding cash price series (nearby prices are the prices closest to the expiration date). The higher the correlation, as measured by the $R^{2}$ statistic, the greater the extent to which movements in cash prices can be explained by movements in futures prices and therefore the more effective the hedging operations. We can measure the 
basis risk by the variability in cash prices not explained by futures price movements, or by $1-R^{2} .^{2}$

To quantify the potential effectiveness of hedging Pakistani wheat on U.S. futures exchanges, we test three futures contracts-no. 1 soft white wheat traded on the Minneapolis Grain Exchange, no. 2 hard red winter wheat traded on the Kansas City Board of Trade, and no. 2 soft red winter wheat traded on the Chicago Board of Trade. We chose these contracts because they cover wheat whose characteristics are closest to those of wheat commonly imported by Pakistan. We collected monthly data for the three contracts from February 1991 (when the Minneapolis contract started trading) to April 1995, providing a total of 51 observations. We first test the correlations against four different import (cash) prices-the U.S. dollar FOB (free on board) price of western white wheat at Pacific Northwest ports, the price of wheat delivered at Karachi, the Karachi price adjusted for EEP, and the Karachi price in Pakistani rupees (table 2). Because we find all the price series to be nonstationary based on the Durbin-Watson test, we transform them by taking first differences. Subsequent tests of the transformed series show them to be stationary in all cases.

We find a high degree of correlation between the wheat futures contract price on the Minneapolis Grain Exchange and the U.S. dollar FOB price of western white wheat quoted at Pacific Northwest ports. The results in table 2 show that variations in the futures prices can explain 89 percent of the variation in the cash prices, with a basis risk of only 11 percent (most likely reflecting variability in transportation costs). This indicates that at least the U.S. dollar FOB price at Pacific Northwest ports faced by Pakistan could be fairly well hedged by trading wheat futures contracts on the Minneapolis Grain Exchange.

We then test correlations between the western white wheat price adjusted for freight charges and the Minneapolis wheat futures contract. Because freight rates between Pacific Northwest ports and Karachi have varied little since early 1991 , the correlation is the same ( $R^{2}$ of 89 percent), with a corresponding basis risk of only 11 percent (table 2). This indicates that hedgers in Pakistan could manage the risk of fluctuating U.S. dollar CIF prices, assuming the government does not implement EEP subsidies.

2. Measuring the basis risk in this manner is sometimes complicated by the statistical properties of time series data. In particular, the validity of testing the correlation between cash and futures prices using regression requires that each price series be stationary. A stationary series is one in which the underlying stochastic process generating the series is invariant with respect to time (that is, the stochastic process is in equilibrium over time about a constant mean level, and the probability of any given fluctuation around that mean level is the same at any point in time). Typically, time series price data are nonstationary because they are influenced by seasonal factors. Fortunately, several straightforward tests for stationarity such as the Durbin-Watson test of Sargan and Bhargava and the Dickey-Fuller test can be performed (Palaskas and Varangis 1991). In most cases, cash and futures price series that are found to be nonstationary can be transformed into stationary series simply by taking first differences (that is, the price in period $T$ minus the price in period $T-1$ ). The differenced series can then be regressed against one another, with the $R^{2}$ coefficient from the regression providing a valid measure of hedging effectiveness and basis rusk. 
Table 2. Hedging Effectiveness, Basis Risk, and Hedge Ratios in Pakistan, 1991-95

\begin{tabular}{|c|c|c|c|}
\hline Contract and price & $R^{2 \mathbf{a}}$ & Basts risk ${ }^{\mathrm{b}}$ & Hedge ratio $^{c}$ \\
\hline \multicolumn{4}{|l|}{ Minneapolis soft white wheat no. 1} \\
\hline FOB U.S. dollar price at Pacific Northwest ports & 0.89 & 0.11 & 0.92 \\
\hline CIF U.S. dollar price at Karachi & 0.89 & 0.11 & 0.94 \\
\hline CIF U.S. dollar price at Karachi adjusted for EEP subsidies & 0.59 & 0.41 & 0.91 \\
\hline CIF rupee price at Karachi adjusted for EEP subsidies ${ }^{d}$ & 0.55 & 0.45 & 0.84 \\
\hline \multicolumn{4}{|l|}{ Kansas City hard red winter wheat no. 2} \\
\hline FОВ U.S. dollar price at Pacific Northwest ports & 0.62 & 0.38 & 0.75 \\
\hline CIF U.S. dollar price at Karachi & 0.61 & 0.39 & 0.76 \\
\hline CIF U.S. dollar price at Karachi adjusted for EEP subsidies & 0.42 & 0.58 & 0.76 \\
\hline CIF rupee price at Karachi adjusted for EEP subsidies ${ }^{d}$ & 0.39 & 0.61 & 0.74 \\
\hline \multicolumn{4}{|l|}{ Chicago soft red winter wheat no. 2} \\
\hline FOB U.S. dollar price at Pacific Northwest ports & 0.50 & 0.50 & 0.66 \\
\hline CIF U.S. dollar price at Karachi & 0.49 & 0.51 & 0.66 \\
\hline CIF U.S. dollar price at Karachi adjusted for EEP subsidies & 0.33 & 0.67 & 0.64 \\
\hline CIF rupee price at Karachi adjusted for EEP subsidies ${ }^{d}$ & 0.30 & 0.70 & 0.65 \\
\hline
\end{tabular}

Note: Calculations are based on monthly observations for February 1991-April 1995 (51 observations). FOB denotes free on board (used to value exports); CIF denotes cost, insurance, and freight (used to value imports); and EEP denotes the U.S. government's Export Enhancement Program.

a. From ordinary least squares regression; cash price $=a+b^{*}$ nearby futures price. All price series were transformed into first differences. Regression period from February 1991 to April 1995.

b. The differences between the futures price in the U.S. and the market price in Pakistan.

c. Slope coefficient regression between first differences of cash and nearby futures prices.

d. Regressions are run from September 1992, the first time Pakistan qualified for EEP subsidies.

Source: International Wheat Council (various issues), U.S. Department of Agriculture (various issues), and authors' calculations.

The picture changes dramatically when we test correlations between Minneapolis futures prices and the U.S. dollar Karachi price of western white wheat adjusted for EEP subsidies. The $R^{2}$ from the regression is only 0.59 , implying a basis risk of 41 percent (table 2). This decline in correlation reflects not only the instability of EEP payments but also the fact that they represent a large percentage of the overall purchase price. The finding also suggests that continuation of subsidies would significantly limit the effectiveness of hedging as a mechanism for managing risk. Converting the CIF Karachi price into rupees yields a slightly lower correlation with the Minneapolis futures prices $\left(R^{2}\right.$ of 0.55$)$, a level also well below that needed to make hedging effective (table 2 ).

We finally test the same set of correlations using the prices of the no. 2 hard red winter wheat futures contract traded on the Kansas City Board of Trade and the no. 2 soft red winter wheat futures contract traded on the Chicago Board of Trade. Overall, changes in the prices of these futures contracts are less correlated with changes in the relevant wheat prices for Pakistan. Even before adjusting for transport costs, EEP subsidies, and exchange rates, changes in the futures price on the Chicago Board of Trade can explain only half the changes in the U.S. dollar western white wheat price at Pacific Northwest ports (table 2). This 
finding indicates that the Chicago wheat futures contract would not be an effective hedging instrument for Pakistani importers.

If there is no basis risk and if changes in futures prices explain all changes in cash prices, hedgers should cover all cash transactions with futures contracts. When there is basis risk, however, hedgers should generally cover only a portion of their cash position. Statistical analysis of cash and futures prices can determine the hedge ratio, an important policy variable.

In Pakistan, the instability of wheat import costs depends on the variability of both the volume and price of imports. However, because the government controls the volume of imports, fluctuating prices are the main source of risk exposure, and controlling price fluctuations is the main objective of risk management strategies. We can view the hedging decision as a portfolio selection problem in which the hedger selects the optimal proportions of unhedged (cash) and hedged (futures) wheat imports. In this case, risk management strategies aim to minimize the variance in the value of the portfolio of hedged and unhedged imports.

Based on portfolio selection theory, we can demonstrate that the optimal hedge ratio is equivalent to the slope coefficient in the ordinary least squares regression between changes in the cash and futures prices (Ederington 1979). Calculating the optimal hedge ratio in this manner, we assume that the hedger seeks to minimize risk. Selecting the portfolio of hedged and unhedged imports that minimizes risk may result in a higher import bill than would otherwise apply. Whether the importers consider the higher import bill acceptable depends on their aversion to risk. Infinitely risk-averse importers seek to minimize risk. Less riskaverse importers are willing to bear some risk in order to reduce the cost of imports. Given the government's concern over commodity price risks, it seems reasonable to assume that the government is infinitely risk averse and to select hedge ratios accordingly.

This assumption may not be justified given our argument that the government is better able to pool and absorb risks than individual farmers and millers. An alternative way to derive an optimal hedge ratio would be to equate the marginal benefit from hedging (measured in terms of the value of risk reduction) with the marginal cost of hedging (brokerage fees). Using the price series with and without hedging, we derive estimates of the risk benefits from hedging based on formulas developed by Newbery and Stiglitz (1981, pp. 93). We calculate the value of risk reduction (risk benefit) for values of the hedge ratio ranging between 0 and 1 and compare it with the cost of hedging in each case. Then, using numerical methods, we determine an optimal value of the hedge ratio at the point where the marginal cost of hedging equals the marginal benefit of hedging. The problem with this approach is that a value for the coefficient of relative risk aversion has to be assumed, which requires specifying the decisionmaker's utility function (in this case the government's). This problem is intractable, and many researchers simply assume a coefficient of relative risk aversion equal to 1 and then measure the sensitivity of the risk benefits to different values of the coefficient (Akiyama and Varangis 1991 and Coleman and Larson 1993). As- 
suming a relative risk aversion coefficient equal to 1 , we obtain an optimal hedge ratio of about 0.85 , which increases to 0.89 for a coefficient of 2 . This indicates that a hedge ratio close to 0.9 would be appropriate for a fairly wide range of assumptions about the government's preferred level of risk.

Assuming risk minimization, hedging the U.S. dollar FOB wheat prices at $\mathrm{Pa}$ cific Northwest ports using the Minneapolis Grain Exchange yields a hedge ratio of 0.92 (table 2). This means that if the government wishes to purchase, say, 2 million tons of wheat, it would need to cover 1.84 million metric tons with futures contracts, or roughly 13,522 contracts (assuming about 136 tons per contract). ${ }^{3}$ Hedge ratios range from 0.91 for the U.S. dollar CIF price adjusted for EEP subsidies to 0.94 for the U.S. dollar CIF price without the subsidy (table 2 ). Hedge ratios decline using the Chicago wheat contract, ranging between 0.64 and 0.66 . In general, the hedge ratios decline as the level of basis risk increases because $R^{2}$ measures the effectiveness of the hedging, and $1-R^{2}$ measures the basis risk. Thus the greater the basis risk, the less effective the hedging, and the lower the basis risk, the more effective the hedging.

The analysis indicates, absent export subsidies, the potential effectiveness of hedging Pakistani wheat purchases using the soft white wheat contract that is traded on the Minneapolis Grain Exchange. The existence of export subsidies severely limits the effectiveness of hedging, however. Two developments suggest that export subsidies may be reduced in the future. The Uruguay Round of the General Agreement on Tariffs and Trade (GATT), which was signed in late 1993, contains a key provision to reduce the overall level of export subsidies (a provision most affecting the United States and the European Union). The agreement calls for a 21 percent decline in the volume of export subsidies and a 36 percent drop in their value from a $1986-90$ base period. In the United States, new farm legislation (the Federal Agricultural Improvement and Reform Act, 1996) has restructured agricultural programs, and budgetary pressures have limited agricultural spending. These developments could result in a reduction of export subsidies below the levels required under the GATT.

\section{ANalysis of Hedging Strategies Using FinanCial InStruments}

The policy of maintaining wheat prices below an equilibrium (import parity price) is not tenable and should be discontinued. Therefore, in this section we outline the policy and institutional environment in which we assume hedging takes place. Other strategies could be developed. For example, the government could abstain from importing wheat when the parity price is below the fixed price, in order to let the private sector import at the import parity price. This would reduce the cost of flour and would also benefit consumers. This policy would work as a call option from the government to wheat millers: the government would subsidize imports as long as the local price is lower than the import

3. All quantities of wheat are measured in metric tons. Each contract is for 5,000 bushels, with 36.74 bushels per metric ton. 
parity price, but when the parity price falls below the fixed price, the government would allow millers to benefit from lower world prices. The government could use hedging to manage its exposure to higher international prices.

We make the following assumptions. The government eliminates the wheat import subsidy and sets a price (the release price) at which it sells imported wheat to mills equal to the expected average import parity price for the coming year. To provide the market with stability, the government announces the release price at the beginning of the year, and that price remains fixed throughout the year. By buying at a variable international price and selling at a fixed domestic price, the government effectively pools the risk of individual market participants and assumes the risk for itself. In particular, the government exposes itself to the risk of international prices rising more than expected, thereby requiring a subsidy to maintain the fixed price. Of course, if the international price falls below the fixed domestic price, the government would impose a tax on wheat imports, bringing the import price up to the domestic price level. Because the international wheat price cannot be predicted accurately, we cannot expect the subsidies required when the international price rises higher than the fixed domestic price to be offset by the revenues received when the international price falls below the fixed domestic price. To manage this risk, the government can hedge using financial instruments. In the following sections, we outline and evaluate the effectiveness of three hedging strategies using futures, options, and swaps. ${ }^{4}$

\section{Strategy I: Hedging with Futures Contracts}

One possible hedging strategy using futures contracts would enable the government to lock in an international price for its wheat purchases at the beginning of the year. This price would equal the weighted sum of wheat futures prices maturing at various months throughout the coming year, with weights determined by the quantities of wheat imported in the months between each contract expiration. Variations of this strategy concentrate or disperse hedging among various contract months. Selection of the month in which to hedge involves judgment and expertise. For the purpose of these examples, we use the conventional hedge approach, matching calendar months with the corresponding futures contract months.

Say, for example, that in December 1993 the government wishes to fix the release price for the 1994 crop. Wheat futures contracts can expire in five different months (March, May, July, September, and December); in December 1993 prices for delivery in each of these months in 1994 are established in the market. On the basis of historical import trends, the government could predict fairly well the proportions of the total import requirements before each of the delivery months (for example, January, February, and March, 10 percent; April and May,

4. The examples do not superimpose hedging strategies on existing parterns and practices of wheat purchases. Instead, the strategies show that hedging with furures can make purchasing much more flexible, lock prices further into the future, and make alternative methods of purchasing wheat more desirable. 
20 percent; June and July, 30 percent; August and September, 25 percent; and October, November, and December, 15 percent). It could use these proportions to obtain a weighted import price for the coming year. The government would guarantee this price and could use it to set the fixed release price assuming expected freight costs, export subsidies, and exchange rates.

We evaluate this strategy using actual cash and futures prices for 1993 and 1994. It should be noted that at the time of this example it is unlikely that the large volume could have been effectively hedged on the Minneapolis Grain Exchange. Contracts from other exchanges (the Chicago Board of Trade and Kansas City Board of Trade) could also have been used, because the Minneapolis Grain Exchange white wheat contract did not have a great deal of liquidity in 1993 and 1994. For simplicity, however, we confine the futures operations aspect of this example to Minneapolis Grain Exchange contracts. This raises two practical issues that need to be addressed with regard to hedging white wheat. First, as already noted, liquidity on the white wheat contract is low and therefore represents a problem for hedging large quantities. Second, we find the basis volatility between the FOB white wheat on the Chicago Board of Trade and Kansas City Board of Trade wheat contracts to be substantially higher than for white wheat futures contracts on the Minneapolis Grain Exchange. However, contract volume on the Minneapolis Grain Exchange white wheat contract is growing, and the prospects of this market providing an adequate hedge in the future are improving. More important, as the role of governments in the export wheat trade declines, the wheat contracts on the Chicago Board of Trade and Kansas City Board of Trade should more closely reflect global export wheat prices. Under these conditions, futures contracts will provide a better hedging mechanism than has been the case in the past. The critical point is that the recent and significant structural changes in the wheat market mean that past relationships between cash and futures prices may not hold in the future, and it is possible that in the new trade environment prices on the Chicago Board of Trade and the Kansas City Board of Trade may better reflect global supply and demand conditions. This being the case, the type of techniques described here would be even more effective for managing price risk than the tools currently available.

In this example, in mid-December 1993 the government decides that for calendar year 1994 it needs about 1.2 million tons of imported white wheat (roughly the average annual volume of imports over the past ten years) and wishes to purchase 100,000 tons each month during the year. The government also wishes to lock in the prevailing mid-December price of $\$ 133$ per ton for the entire purchase, on the basis of which it announces the fixed release price (assuming expected freight costs, export subsidies from suppliers, and exchange rates). In executing the strategy, the government buys 100,000 tons of wheat on the first trading day of each month and buys and sells futures contracts with expiration dates coinciding with future purchases.

Table 3 gives the monthly transactions and net positions for this strategy. Here we discuss two months, January and December, to illustrate how the hedg- 
Table 3. Analysis of Cash and Futures Transactions

(U.S. dollars per ton unless otherwise noted)

\begin{tabular}{|c|c|c|c|c|c|c|c|c|}
\hline \multirow[b]{2}{*}{$\begin{array}{l}\text { Date of } \\
\text { transactions (1994) }\end{array}$} & \multirow[b]{2}{*}{$\begin{array}{c}\text { Cash price } \\
\text { paid }\end{array}$} & \multicolumn{6}{|c|}{ Futures transactions" } & \multirow[b]{2}{*}{$\begin{array}{c}\text { Net position } \\
\text { (effective price } \\
\text { paid) }\end{array}$} \\
\hline & & $\begin{array}{c}\text { Contract } \\
\text { expiration date } \\
\text { (1994) }\end{array}$ & $\begin{array}{c}\text { Date } \\
\text { bought }\end{array}$ & $\begin{array}{l}\text { Futures price } \\
\text { paid }\end{array}$ & $\begin{array}{l}\text { Futures price } \\
\text { received }\end{array}$ & Gain $^{b}$ & $\begin{array}{c}\text { Gain with } \\
\text { hedge ratio }\end{array}$ & \\
\hline January 3 & 133.4 & March & $12 / 16 / 93$ & 136.7 & 136.5 & -0.18 & -0.17 & 133.7 \\
\hline February 1 & 130.4 & March & $12 / 16 / 93$ & 136.7 & 132.3 & -4.40 & -4.05 & 134.6 \\
\hline March 1 & 127.5 & March & $12 / 16 / 93$ & 136.7 & 129.0 & -7.71 & -7.09 & 134.7 \\
\hline April 4 & 126.8 & May & $12 / 16 / 93$ & 136.3 & 130.1 & -6.25 & -5.75 & 132.7 \\
\hline May 2 & 137.8 & May & $12 / 16 / 93$ & 136.3 & 139.4 & 3.12 & 2.87 & 135.1 \\
\hline June 1 & 134.1 & July & $1 / 1 / 94$ & 134.1 & 133.4 & -0.73 & -0.67 & 134.9 \\
\hline July 1 & 132.3 & July & $1 / 1 / 94$ & 134.1 & 134.1 & 0.00 & 0.00 & 132.4 \\
\hline August 1 & 127.9 & September & $2 / 16 / 94$ & 131.5 & 133.4 & 1.84 & 1.69 & 126.3 \\
\hline September 1 & 147.0 & September & $2 / 16 / 94$ & 131.5 & 150.6 & 19.10 & 17.57 & 129.5 \\
\hline October 3 & 169.0 & December & $3 / 1 / 94$ & 130.4 & 174.5 & 44.09 & 40.56 & 128.6 \\
\hline November 1 & 166.4 & December & $3 / 1 / 94$ & 130.4 & 169.4 & 38.95 & 35.83 & 130.7 \\
\hline December 1 & 164.2 & December & $3 / 1 / 94$ & 130.4 & 166.5 & 36.01 & 33.13 & 131.3 \\
\hline
\end{tabular}

Note: In the hedging strategy represented here, the government purchases 100,000 tons of wheat on the first trading day of each month. It buys and sells futures contracts with expiration dates coinciding with future purchases. See section IV of the text.

a. The quantity purchased is 92,000 tons, equivalent to 676 futures contracts. The brokerage fee is $\$ 0.15$ per ton.

b. Price received minus price paid.

c. The gain times the hedge ratio of 0.92 .

d. The cash price minus the gain with the hedge ratio plus the brokerage fee.

Source: International Wheat Council (various issues), U.S. Department of Agriculture (various issues), and authors' calculations. 
ing operates. On January 3,1994, the government purchases 100,000 tons of wheat on the international market at a price of $\$ 133.40$ per ton. On the same day, it sells 676 of the March futures contracts at a price of $\$ 136.50$ per ton. Buying the March futures at $\$ 136.70$ per ton and selling them at $\$ 136.50$ yields a loss of $\$ 0.18$ per ton, or $\$ 0.17$ per ton with the 0.92 hedge ratio. Including a brokerage fee of $\$ 0.15$ per ton, the government pays an effective price of $\$ 133.70$ per ton $(\$ 133.40$ per ton cash price plus $\$ 0.17$ per ton loss from the futures transaction plus the $\$ 0.15$ per ton brokerage fee). By comparison, on December 1,1994 , the government purchases 100,000 tons of wheat on the international market at a price of $\$ 164.20$ per ton. On the same day, it sells 676 of the December futures contracts at a price of $\$ 166.40$ per ton. Buying the December futures back in March at $\$ 130.40$ per ton and selling them at $\$ 166.40$ per ton in December yields a profit of $\$ 36.01$ per ton, or $\$ 33.13$ per ton with the 0.92 hedge ratio. Including a brokerage fee of $\$ 0.15$ per ton, the government pays an effective price of $\$ 131.30$ per ton $(\$ 164.20$ per ton cash price less $\$ 33.10$ per ton gain from the futures transaction plus the $\$ 0.15$ per ton brokerage fee).

The pattern of cash wheat prices shows a decline into April of 1994 followed by strong price increases in the succeeding months. It is important to remember that the primary objective of the hedging strategy is to establish an import price at or near the desired level of $\$ 133$ per ton. Losing sight of this will lead to the erroneous conclusion that it would be better not to have hedged purchases up to April 1994, a period of declining market prices.

Figure 1 and the first two columns of table 4 present a comparison of the gross FOB import price (what the government would pay if it had not hedged) and the net FOB import price (the price that it would pay for white wheat FOB Portland net of brokerage charges and including the gain or loss from futures transactions). With hedging, the government would pay a lower price in six of the twelve months; in two of the remaining six months the difference in the net import price is less than $\$ 1$ per metric ton.

It is also informative to look at the total import cost for wheat under each scenario. Under the nonhedged scenario (gross FOB import price) total expenditure is PRs6.1 billion (average monthly price times import volume of 1.2 million tons); under the hedged scenario (net FOB import price) total expenditure is PRs5.7 billion (table 4). Clearly the government is better off having hedged.

The results also show the effectiveness of hedging for reducing the variability of import costs. If the government had not hedged, the monthly import bill would range from PRs460 million in April to PRs589 in October, with the biggest month to month change between September and October, when the cost increases PRs67 million (from PRs522 million to PRs589 million; table 4). If the government had hedged, the import cost would vary only slightly, with a difference between the highest and lowest months' payments of less than PRs30 million.

Assume also that the government sets a release price for the year of PRs4,800 (equivalent to an FOB price of $\$ 133$ per ton). If the government had not hedged, 
Table 4. The Impact of the Futures Hedging Program on Wheat Import Payments

\begin{tabular}{|c|c|c|c|c|c|c|c|c|c|c|c|}
\hline \multirow[b]{3}{*}{ Month } & \multirow{2}{*}{\multicolumn{2}{|c|}{$\begin{array}{c}\text { FOB price } \\
\text { (dollars per ton) }\end{array}$}} & \multirow{2}{*}{\multicolumn{2}{|c|}{$\begin{array}{c}\text { CIF price } \\
\text { (rupees per ton) }\end{array}$}} & \multirow{2}{*}{\multicolumn{2}{|c|}{$\begin{array}{c}\text { Import cost } \\
\text { (millions of rupees) }\end{array}$}} & \multirow{3}{*}{$\begin{array}{c}\text { Release } \\
\text { price } \\
\text { (rupees } \\
\text { per ton) }\end{array}$} & \multicolumn{4}{|c|}{ Illustrative government subsidy or tax ${ }^{\mathrm{b}}$} \\
\hline & & & & & & & & \multicolumn{2}{|c|}{ Rupees per ton } & \multicolumn{2}{|c|}{ Millions of rupees } \\
\hline & $\begin{array}{l}\text { Without } \\
\text { hedging }\end{array}$ & $\begin{array}{c}\text { With } \\
\text { hedging }\end{array}$ & $\begin{array}{l}\text { Without } \\
\text { bedging }\end{array}$ & $\begin{array}{c}\text { With } \\
\text { hedging }\end{array}$ & $\begin{array}{l}\text { Without } \\
\text { hedging }\end{array}$ & $\begin{array}{c}\text { With } \\
\text { hedging }\end{array}$ & & $\begin{array}{l}\text { Without } \\
\text { bedging }\end{array}$ & $\begin{array}{c}\text { With } \\
\text { bedging }\end{array}$ & $\begin{array}{l}\text { Without } \\
\text { hedging }\end{array}$ & $\begin{array}{c}\text { With } \\
\text { hedging }\end{array}$ \\
\hline January & 133.4 & 133.7 & 4,800 & 4,810 & 480.0 & 481.0 & 4,800 & 0 & -10 & 0.0 & -1.0 \\
\hline February & 130.4 & 134.6 & 4,710 & 4,839 & 471.0 & 483.9 & 4,800 & 90 & -39 & 9.0 & -3.9 \\
\hline March & 127.5 & 134.7 & 4,621 & 4,842 & 462.1 & 484.2 & 4,800 & 179 & -42 & 17.9 & -4.2 \\
\hline April & 126.8 & 132.7 & 4,598 & 4,778 & 459.8 & 477.8 & 4,800 & 202 & 22 & 20.2 & 2.2 \\
\hline May & 137.8 & 135.1 & 4,935 & 4,852 & 493.5 & 485.2 & 4,800 & -135 & -52 & -13.5 & -5.2 \\
\hline June & 134.1 & 134.9 & 4,822 & 4,847 & 482.2 & 484.7 & 4,800 & -22 & -47 & -2.2 & -4.7 \\
\hline July & 132.3 & 132.4 & 4,767 & 4,771 & 476.7 & 477.1 & 4,800 & 33 & 29 & 3.3 & 2.9 \\
\hline August & 127.9 & 126.3 & 4,632 & 4,585 & 463.2 & 458.5 & 4,800 & 168 & 215 & 16.8 & 21.5 \\
\hline September & 147.0 & 129.5 & 5,215 & 4,683 & 521.5 & 468.3 & 4,800 & -415 & 117 & -41.5 & 11.7 \\
\hline October & 169.0 & 128.6 & 5,887 & 4,655 & 588.7 & 465.5 & 4,800 & $-1,087$ & 145 & -108.7 & 14.5 \\
\hline November & 166.4 & 130.7 & 5,806 & 4,718 & 580.6 & 471.8 & 4,800 & $-1,006$ & 82 & -100.6 & 8.2 \\
\hline December & 164.2 & 131.3 & 5,741 & 4,735 & 574.1 & 473.5 & 4,800 & -941 & 65 & -94.1 & 6.5 \\
\hline Total & & & & & $6,053.4$ & $5,711.4$ & & & & -293.4 & 48.6 \\
\hline Average & 141.4 & 132.0 & 5,044 & 4,756 & 504.5 & 475.9 & 4,800 & -244.5 & 40.5 & -24.5 & 4.1 \\
\hline
\end{tabular}

Note: The government purchases 100,000 tons of wheat each month. FOB denotes free on board (used to value exports), and CIF denotes cost, insurance, and freight (used to value imports).

a. FOB price is converted into a CIF price by adding a freight cost of $\$ 24$ per ton, assuming no export subsidies and using an exchange rate of PRs30.5 per dollar. b. A negative value is a subsidy; a positive value is a tax.

Source: International Wheat Council (various issues), U.S. Department of Agriculture (various issues), and authors' calculations. 
Figure 1. Hedging Effectiveness Using Futures

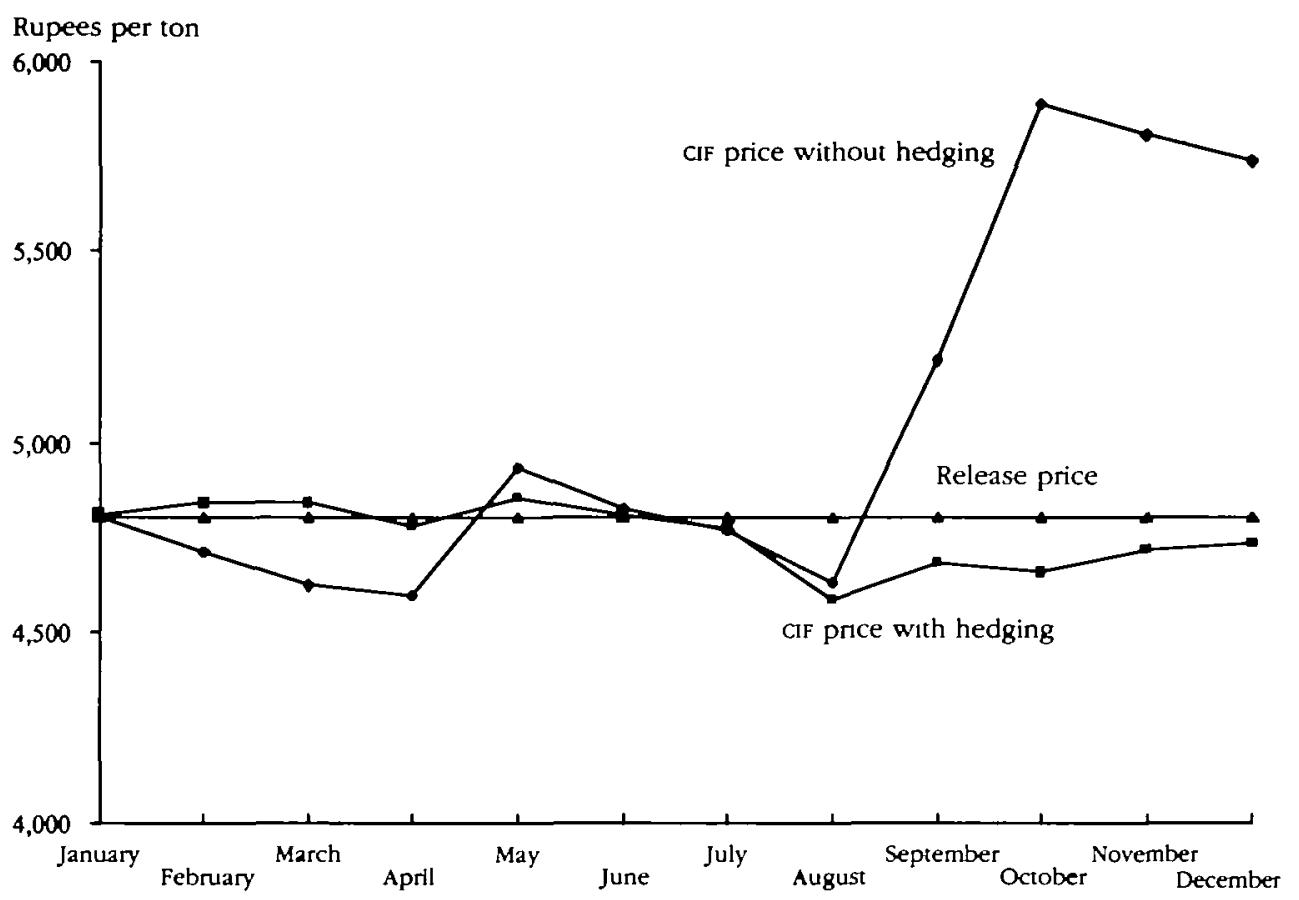

Sounce. Table 4.

the unexpected rise in prices toward the end of the year would result in huge subsidy payments of PRs 293 million for the entire year. These payments would be required because of the increase in international prices of more than $\$ 40$ per ton between August and October. However, having hedged and locked in a price, the government does not incur subsidy payments.

This hedging program results in a lower total import cost because market prices increase in the later half of the year. However, lowering the import bill is not the goal of the hedging program, and the program should not be considered successful because it is profitable. If international prices fall, the government would end up paying more in subsidies than if it had not hedged. Payment of additional subsidies would not indicate failure of the strategy, however. The hedging strategy is a success because it reduces the volatility of international prices and the cost of imports, enabling the government to manage its finances better, and not because it reduces the overall cost of imports and thereby saves the government money. In the long run the government can expect neither to gain nor to lose money through hedging, and the cost of using hedging instruments is equal to the brokers' fees on the contracts.

\section{Strategy II: Hedging with Options Contracts}

A second strategy involves the purchase of call options. This example involves a slightly different purchasing arrangement than in the futures illustra- 
tion. However, this difference does not invalidate the overall result and message of the article-that hedging with any of the three instruments would help the government to manage its price risk. The choice between using futures vis-à-vis options depends on the preferred risk of the government. Options are different from futures in that the former hedges against price movements in one direction only (buying an option is much like buying insurance), while futures insulate hedgers from price movements in both directions. Therefore, perhaps it is inappropriate to make direct comparisons between options and futures.

Call options give the holder the right to buy a specific commodity at a specified strike price. In a sense, call options provide insurance against prices rising at a later date. The use of call options is appropriate for the government of Pakistan in managing future wheat imports. A call option differs from a futures contracts strategy in that a futures contract locks in the import price. A downside of the futures hedging strategy is that if prices decline, the government cannot take advantage of lower prices and incurs higher subsidy payments than if it had not hedged. Purchasing a call option enables the buyer to establish a maximum price for a commodity by providing protection from upward price movements while at the same time allowing the buyer to participate in the benefits of downward price movements of the underlying commodity. The premium paid for the option is the cost of receiving the upward price protection and can be viewed as the "insurance policy" premium.

A specific hedging strategy using options contracts would work as follows. In January 1994 the government decides to import 1.2 million tons of wheat during the calendar year. It also decides to make half the purchases during the second quarter and half during the fourth quarter (with purchases of 600,000 tons in each case). In early January, U.S. exporters offer a price of $\$ 135$ per ton. If the government believes that prices could move lower during the year, it would prefer to delay its purchase of the wheat until the time of actual delivery. By waiting, however, the government risks the possibility that prices will rise, increasing the cost of imports. In effect, the government would like to participate in any downward move in prices while at the same time protecting itself against upward changes in price. In early February 1994 the government decides to import the first 600,000 tons of wheat during the month of April. It would like to lock in the $\$ 135$ per ton price being offered for April delivery but be able to benefit if wheat prices fall. To accomplish this objective, on February 7, 1994, the government purchases 4,410 May white wheat call options (equivalent to 600,000 tons) with a strike price of $\$ 132.28$ per ton. The cost of these options is $\$ 3.86$ per ton. As noted above, physical cash white wheat FOB Portland for April at this time is trading at $\$ 135$ per ton, and the May futures contract is trading for $\$ 133.19$ per ton. In purchasing these call options, the government buys the right (or option) to purchase white wheat futures at $\$ 132.28$ per ton.

By April, May futures are trading at $\$ 130.07$ per ton, cash white wheat FOB Portland is trading at $\$ 126.77$ per ton, and May white wheat options with a $\$ 132.28$ per ton strike price are worth $\$ 0.37$ per ton. Given that the May fu- 
tures price ( $\$ 130.07$ per ton) is below the $\$ 132.28$ per ton strike price, the options held by the government have little value and will likely expire worthless. Physical cash prices, however, have followed the general price decline, and the government can purchase its wheat at prices that are substantially lower than those that prevailed in January. Although in this case the price protection is not exercised, the government has the flexibility to wait for lower prices, because its upside risk is covered by the options.

The government pays the cash price of $\$ 126.77$ per ton, plus the net cost of options of $\$ 3.49$ per ton ( $\$ 3.86$ purchase price less $\$ 0.37$ sale price) plus a $\$ 0.10$ per ton brokerage fee, yielding a net of $\$ 130.36$ per ton $-\$ 3.59$ per ton more than if it does not hedge. Although hedging results in a higher price paid, the strategy is nevertheless appropriate because it protects the government against an increase in prices. The difference between the $\$ 130.36$ per ton paid and the cash price of $\$ 126.77$ per ton ( $\$ 3.59$ per ton) represents the insurance premium for guaranteeing a price of no more than $\$ 132.28$ per ton. Relative to the February forward price of $\$ 135$ per ton, the effective price of $\$ 130.36$ per ton represents a saving of $\$ 4.64$ per ton, a reduction of $\$ 2.8$ million in import costs.

In April 1994 the government wishes to purchase the remaining 600,000 tons of white wheat for delivery in November of 1994 . The situation is such that no FОВ offers for white wheat in Portland are currently available for November or December delivery. However, the December white wheat futures on the Minneapolis Grain Exchange are trading at $\$ 129.97$ per ton. In addition, December white wheat call options with a $\$ 128.60$ per ton strike price are trading at $\$ 4.78$ per ton. The government decides to purchase 4,410 December call options with the $\$ 128.60$ strike price as protection against a price increase. As in the April hedge, the government has protected itself from upside price risk but is still able to reap the benefit of price declines in the physical cash market.

When November 1994 arrives, December futures are trading at $\$ 169.39$ per ton, cash white wheat FOB Portland is worth $\$ 166.36$ per ton, and December white wheat options with a $\$ 128.60$ strike price are worth $\$ 40.79$ per ton. Obviously, white wheat prices have increased substantially, as reflected in the futures price, the options price, and the physical cost of FOB white wheat. Because the futures price exceeds the strike price, the government exercises its right to purchase futures at $\$ 128.60$ per ton, because these contracts are now worth $\$ 169.39$ per ton. The government can then sell the futures contracts for a profit of $\$ 40.79$ and purchase the physical cash wheat for $\$ 166.36$ per ton.

To evaluate the actual cost of the wheat purchase taking the options hedging operation into consideration, we subtract the price of the option $(\$ 40.79$ per ton) from the wheat purchase price ( $\$ 166.36$ per ton) and add back the original cost of the option $(\$ 4.78)$ and brokerage fee $(\$ 0.10)$, yielding a net purchase price of $\$ 130.45$ per ton. The use of options contracts enables the purchaser to protect itself against upside price risk. If prices fall, the buyer of the option also benefits. In this case, the government has reduced its import bill by $\$ 21.5$ million by hedging. 
Table 5. The Impact of the Options Hedging Program on Wheat Import Payments

\begin{tabular}{|c|c|c|c|c|c|c|c|c|c|c|c|}
\hline \multirow[b]{3}{*}{ Month } & \multirow{2}{*}{\multicolumn{2}{|c|}{$\begin{array}{c}\text { FOB price } \\
\text { (dollars per ton) }\end{array}$}} & \multirow{2}{*}{\multicolumn{2}{|c|}{$\begin{array}{c}\text { CIf prices } \\
\text { (rupees per ton) }\end{array}$}} & \multirow{2}{*}{\multicolumn{2}{|c|}{$\begin{array}{c}\text { Import cost } \\
\text { (millions of rupees) }\end{array}$}} & \multirow{3}{*}{$\begin{array}{l}\text { Release } \\
\text { price } \\
\text { (rupees } \\
\text { per ton) }\end{array}$} & \multicolumn{4}{|c|}{ Illustrative government subsidy or tax } \\
\hline & & & & & & & & \multicolumn{2}{|c|}{ Rupees per ton } & \multicolumn{2}{|c|}{ Millions of rupees } \\
\hline & $\begin{array}{l}\text { Without } \\
\text { hedging }\end{array}$ & $\begin{array}{c}\text { With } \\
\text { bedging }\end{array}$ & $\begin{array}{l}\text { Without } \\
\text { bedging }\end{array}$ & $\begin{array}{c}\text { With } \\
\text { hedging }\end{array}$ & $\begin{array}{l}\text { Without } \\
\text { bedging }\end{array}$ & $\begin{array}{c}\text { With } \\
\text { hedging }\end{array}$ & & $\begin{array}{l}\text { Without } \\
\text { hedging }\end{array}$ & $\begin{array}{c}\text { With } \\
\text { hedging }\end{array}$ & $\begin{array}{l}\text { Without } \\
\text { hedging }\end{array}$ & $\begin{array}{c}\text { With } \\
\text { hedging }\end{array}$ \\
\hline April & 126.8 & 130.4 & 4,598 & 4,709 & 2,759 & 2,826 & 4,800 & 202 & 91 & 121 & 54 \\
\hline November & 166.4 & 130.5 & 5,806 & 4,712 & 3,484 & 2,827 & 4,800 & $-1,006$ & 88 & -604 & 53 \\
\hline Total & & & & & 6,243 & 5,653 & & & & -483 & 107 \\
\hline Average & 146.6 & 130.5 & 5,202 & 4,711 & 3,121 & 2,826 & 4,800 & -402 & 89 & -241 & 54 \\
\hline
\end{tabular}

Note: The government purchases 600,000 tons of wheat in April and 600,000 tons in November. FOB denores free on board (used to valuc exports), and CIF denotes cost, insurance, and freight (used to value imports).

a. FOB price is converted into a ClF price by adding a freight cost of $\$ 24$ per ton, assuming no export subsidies and using an exchange rare of PRs 30.5 per dollar.

b. A negative value is a subsidy; a positive value is a tax.

Source: International Wheat Council (various issues), U.S. Department of Agriculture (various issues), and authors' calculations. 
Table 5 shows the impact of the options hedging program on government subsidy payments. Over the year, the average FOB price with hedging is $\$ 130.50$ per ton compared with $\$ 146.60$ per ton without hedging, resulting in PRs 590 million savings on imports. The policy of establishing a PRs4,800 per ton release price would cost the government PRs483 million without the options hedging, compared with PRs107 million in revenues with hedging.

\section{Strategy III: Hedging with Swaps}

A third hedging alternative is to use a commodity swap. Swaps were developed to manage relatively long-term risk and are generally available on the overthe-counter market (that is, they are negotiated between parties rather than traded on an exchange). Swaps are purely financial instruments in that no exchange of physical goods takes place. This feature distinguishes swaps from futures and options contracts, in which the parties can make or take delivery of the physical (agricultural) commodity. (In practice, of course, only the net amounts change hands.)

The hedger utilizes swaps to shift price risk to the investment community and to manage the price risk of the commodity portfolio of the business. A swap transaction accomplishes this by establishing three variables: the amount or volume of the swap, a fixed price level, and a variable price level. Fluctuations of the variable price around the fixed price are used to establish a stream of payments to each party to the swap. A swap with two parties typically involves a consumer of the commodity and a producer; a bank or other type of financial institution acts as intermediary. The consumer pays the fixed price amount and receives the variable price amount. The producer receives the fixed price amount and pays the variable price amount.

The great advantage of swaps is that they afford great flexibility by decoupling the hedging activity from the physical trading activities of an organization. Swaps also enable an organization to manage price risk for relatively long periods of time. Their major drawback is that they require cash flow and are very credit intensive. Because swap transactions involve a high counterparty risk, banks may require up-front cash collateral (in an escrow offshore account that could be earning interest) to cover a predetermined level of risk exposure. The underdeveloped market for swaps in the agricultural area presents another drawback; to date most swaps of physical commodities have been in metals and petroleum.

To see how a swap would work, assume that the government wants to secure a long-term price of wheat equal to $\$ 135$ per ton. It enters into a swap agreement with a bank such that the fixed price of the swap is $\$ 135$ per ton and the variable price used is the monthly average price of the nearby white wheat futures contract traded on the Minneapolis Grain Exchange. The amount is 100,000 tons per month. At the end of each month the price of white wheat on the exchange is averaged, and the fixed price of the swap ( $\$ 135$ per ton) is subtracted from the variable price to determine the payment to be made to or received from the government. Assume that prices average $\$ 127$ per ton in the first month and 
$\$ 145$ per ton in the second month. The government pays the bank $\$ 8$ per ton, or $\$ 800,000$, the first month and receives $\$ 10$ per ton, or $\$ 1,000,000$, the second month. The cash flows from the swap transaction apply against the actual physical market transactions the government undertakes in the white wheat market. Presumably in the first month the government purchases 100,000 tons of white wheat at $\$ 8$ per ton less than the fixed price; the next month the price in the physical market is $\$ 10$ per ton higher.

Applying the swap concept to wheat purchases during 1994 yields the results shown in tables 6 and 7 and in figure 2. The example uses spot cash white wheat values from 1994 and assumes a desired import price of $\$ 135$ per ton (this price constitutes the fixed price level).

The financial intermediary charges a 1 percent commission for the service of arranging the swap. The variable price used as a reference is the average Minneapolis nearby futures price (column one in table 6). The government imports 100,000 tons of wheat per month, or 1.2 million tons for the entire 1994 year. In table 6 , the price paid in the actual physical cash market (fourth column) is adjusted by the net payment to achieve a net (or effective) price close to the target price of $\$ 135$ per ton (fifth column). In fact, the average cash price paid for all of 1994 in the actual physical cash market is $\$ 141$ per ton.

Table 7 shows the impact of using the swap agreement on import costs. Without the swap mechanism the government would pay a total of PRs6.05 billion

\section{Figure 2. Hedging Effectiveness Using Swaps}

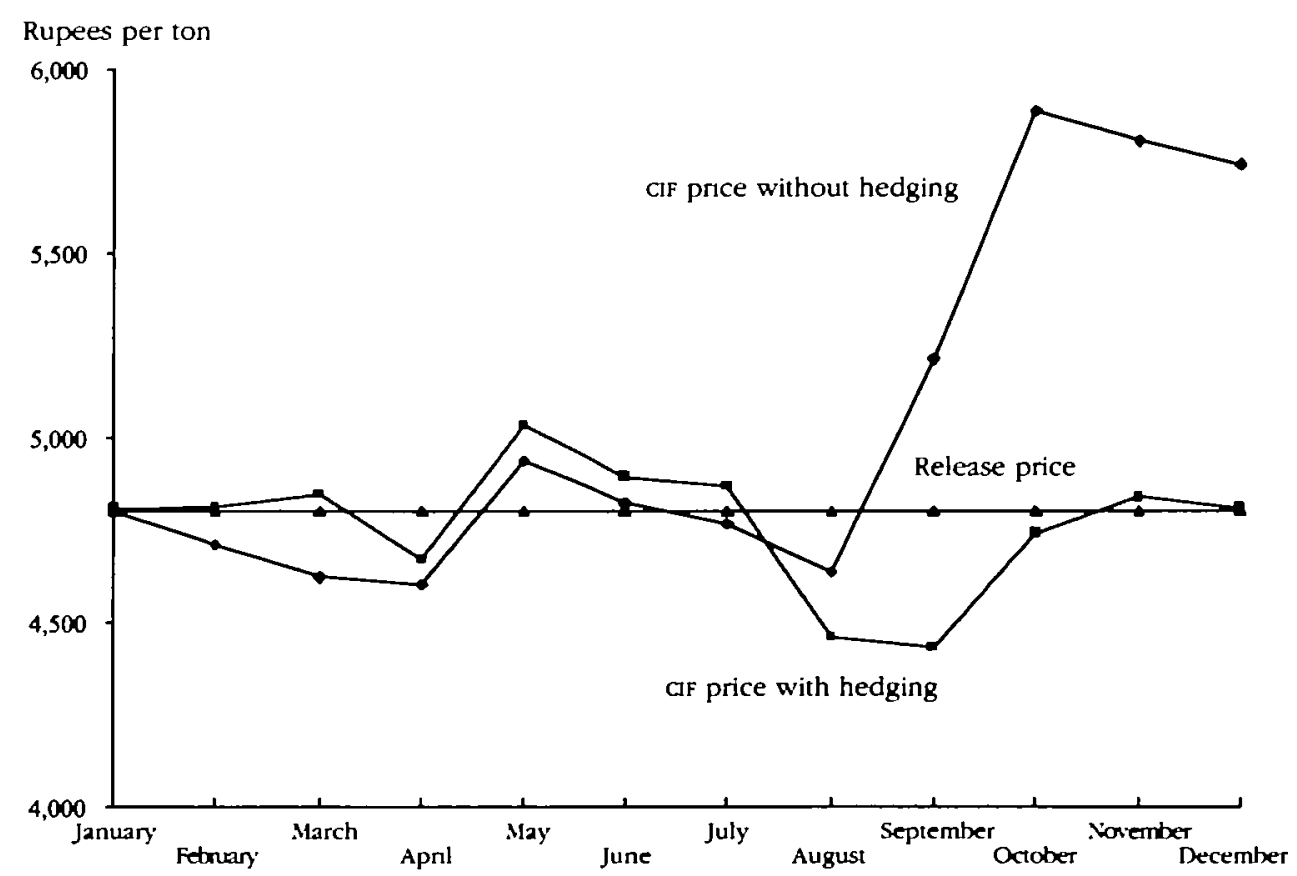

Source. Table 7. 
Table 6. Calculation of the Net Wheat Import Price for the Strategy of Hedging with Swaps

(U.S. dollars per ton)

\begin{tabular}{lccccc}
\hline & $\begin{array}{c}\text { Average } \\
\text { Minneapolis } \\
\text { Mutures price }\end{array}$ & $\begin{array}{c}\text { Fixed target } \\
\text { price }\end{array}$ & Net payment & Cash price & Net price \\
\hline January & 136.4 & 135.0 & 1.4 & 133.4 & 133.3 \\
February & 132.8 & 135.0 & -2.2 & 130.4 & 134.0 \\
March & 128.6 & 135.0 & -6.4 & 127.5 & 135.2 \\
April & 134.3 & 135.0 & -0.7 & 126.8 & 128.8 \\
May & 137.4 & 135.0 & 2.4 & 137.8 & 136.7 \\
June & 133.6 & 135.0 & -1.4 & 134.1 & 136.9 \\
July & 133.0 & 135.0 & -2.0 & 132.3 & 135.6 \\
August & 142.4 & 135.0 & 7.4 & 127.9 & 121.8 \\
Seprember & 161.7 & 135.0 & 26.7 & 147.0 & 121.6 \\
October & 173.9 & 135.0 & 38.9 & 169.0 & 131.5 \\
November & 168.3 & 135.0 & 33.3 & 166.4 & 134.4 \\
December & 167.3 & 135.0 & 32.3 & 164.2 & 133.3 \\
\hline
\end{tabular}

Note: Values are the net free on board (FOB) wheat import price.

a. Average Minneapolis futures price minus fixed price of $\$ 135$ per ton.

b. Price actually paid in the market.

c. Price actually paid in the market minus net payment plus 1 percent brokerage fee ( $\$ 1.35$ per ton).

Source: International Wheat Council (various issues), U.S. Department of Agriculture (various issues), and authors' calculations.

for wheat purchases in 1994; utilizing a swap mechanism the payment would be only PRs5.71 billion. Assuming a release price of PRs4,800 per ton as in the previous two examples, the wheat swap significantly reduces the variability of subsidy payments and tax revenues. With the swap, the monthly payments and revenues range from PRs10.8 million in subsidies to PRs35.8 million in taxes; without the swap, payments and revenues range from PRs108.7 million in subsidies to PRs20.2 million in taxes. More important, the swap arrangement allows the government to avoid the net cost of PRs293.4 million in subsidy payments that would result if the government had not hedged.

In this example, one advantage of utilizing a swap rather than futures and options is that the consuming entity (in this case the government) does not have to worry about liquidity problems on the exchange or the mechanics and strategy of executing futures and options contracts. Care must be taken, however, to ensure that the variable price used has a strong relationship with the actual physical cash market and cannot be manipulated.

\section{CONCLUSIONS}

This article has some important implications for future wheat policy in Pakistan. Domestic wheat prices have been largely isolated from world markets, and the government has succeeded in reducing price fluctuations. However, the policy does not remove risk from the economy as a whole but merely transfers the risk from wheat market participants in the form of unstable prices to the govern- 
Table 7. The Impact of the Swaps Futures Hedging Program on Wheat Import Payments

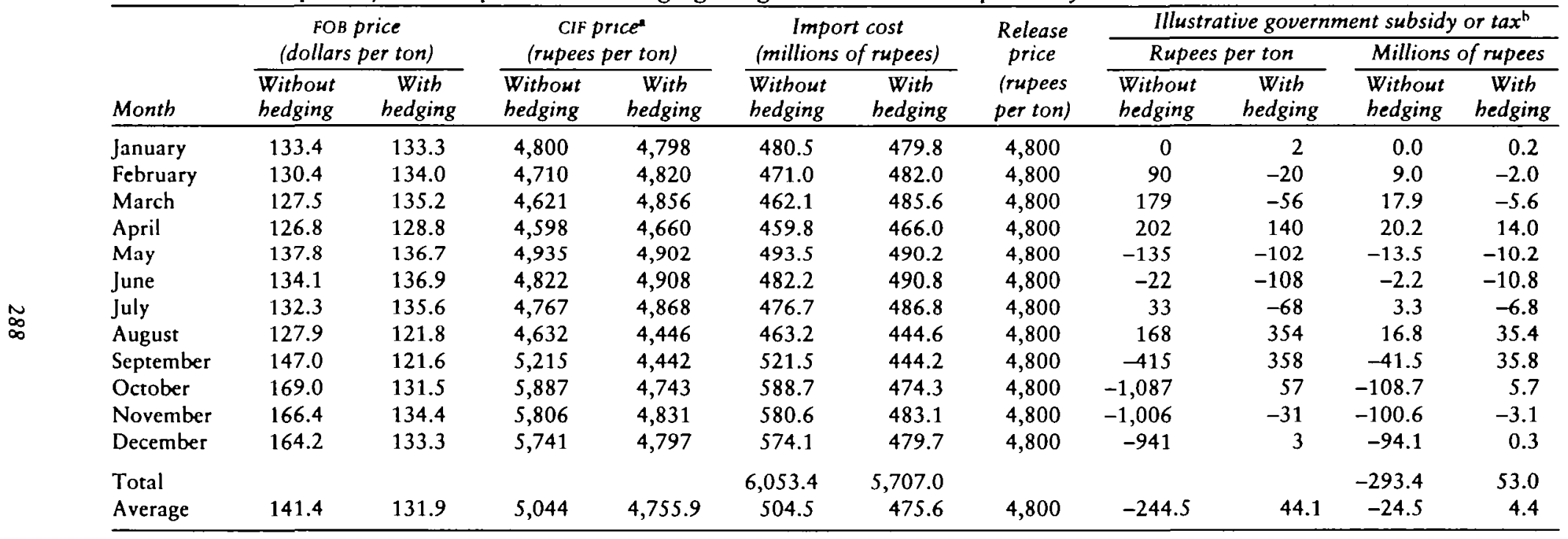

Note: The government purchases 100,000 tons of wheat each month. FOB denotes free on board (used to value exports), and clf denotes cost, insurance, and freight (used to value imports).

a. FOB price is converted into a CIF price by adding a freight cost of $\$ 24$ per ton, assuming no export subsidies, and using an exchange rate of PRs 30.5 per dollar. b. A negative value is a subsidy; a positive value is a tax.

Source: International Wheat Council (various issues), U.S. Department of Agriculture (various issues), and authors' calculations. 
ment (and ultimately taxpayers throughout the economy) in the form of unstable subsidy payments. The current system provides farmers and millers with little incentive to undertake risk management on their own behalf. The private sector has little need to worry about fluctuating prices when making production and investment decisions. In effect, the government has crowded out private sector risk management activities.

Overall, the government is the entity most exposed to price variability. Given the large number of relatively small wheat farmers and traders, market participants cannot pursue risk management strategies on their own. The current structure of risk distribution, whereby the government pools the risk of small producers and traders, may therefore be appropriate. However, having assumed the price risk, the government needs to manage it by taking advantage of mechanisms to externalize the price risk or transfer it to other entities.

Commodity hedging could be a useful method of managing commodity price risks as long as the market participants understand the mechanisms and the government keeps regulatory, legal, and institutional barriers to a minimum. The government and potential market participants must well understand the nature of hedging, the various instruments available, the potential obstacles, and practical considerations. In particular, commodity hedging using futures, options, and swaps could significantly reduce the variability of the cost of imports. The simulations of actual hedging strategies indicate that hedging would reduce the variability of import costs, thereby facilitating the management of public expenditures and planning. Other mechanisms for price stabilization generally cost more than hedging. If the government needs to borrow to finance additional subsidies resulting from unforeseen increases in international wheat prices, the cost of borrowing represents the cost of not hedging. Although hedging involves risks and costs, not hedging may be riskier and costlier. However, commodity hedging operations, which involve simultaneous transactions in cash and futures markets, can be complex and hence require specialized expertise. Of the instruments evaluated, swaps could be more attractive than futures and options because they are easier to implement and financial intermediaries are available to facilitate the transactions.

In searching for alternatives to the current system, the government of Pakistan should consider hedging using futures, options, and swaps, as well as other methods of price stabilization. The government has already considered developing an agricultural buffer fund (Afzal and others 1993). Another possible alternative would be to borrow and lend in international credit markets to cover unexpected subsidy payments associated with fluctuating commodity prices. Such self-insurance schemes differ from hedging in that they are ex post and require action once unfavorable movements in commodity prices have occurred, while hedging provides ex ante insurance against such price movements. Deaton (1992), however, argues that implementation of self-insurance schemes may be problematic due to the time series properties of commodity prices. Commodity prices tend to have persistent and large swings and a significant element of uncertainty. 
Therefore, the government would have to borrow an uncertain amount for an uncertain period of time. During periods of persistently low commodity prices, Deaton argues, the amount required could be substantial. Also, when commodity prices are low, borrowing countries are less creditworthy and therefore are more risky to the lender. However, stabilization funds and buffer stock schemes can be used in conjunction with hedging. For example, Claessens and Varangis (1994) show how a stabilization fund can be significantly cheaper to operate if hedging instruments are used to cover extreme movements in commodity prices, thereby allowing a buffer fund to cover price movements within a narrow range of prices.

The future configuration of the global wheat environment holds a special significance for wheat import practices in Pakistan. Changes in this environment could affect how Pakistan imports wheat, from whom it imports, and at what price it imports. Transformation of the global environment could result from changes in both the policy environment and the fundamental supply-demand situation. From a policy standpoint, the general trend in global economies is to reduce government spending and adopt more market-oriented policies. The context for these changes was the GATT negotiations that led to the formation of the World Trade Organization and a phased reduction of agricultural subsidies. This reduction has already led to reforms in the Common Agriculture Policy of the European Union, which were first instituted in 1992 and continued to be implemented through at least 1996. These reforms have lowered guaranteed wheat prices and have led to lower planted acreage, lower production, and lower intervention stocks of wheat.

The volatility of prices and the absolute price level of wheat are likely to increase relative to the level of the 1980s. As a result, the cost of imported wheat will likely be higher for Pakistan than it has been in the past 10 years. Higher world wheat prices in themselves could lead to lower subsidies for export wheat in that as prices rise governments need to provide less in subsidies to make their own wheat competitive in world markets. Most likely, the market changes we describe here will produce a more amenable environment for hedging world prices of wheat on U.S.-based futures exchanges. With U.S. prices less isolated from global factors (in part because of lower subsidies), U.S. wheat futures prices should be more highly correlated with world wheat prices than has been the case in the past. This could mean that countries such as Pakistan should find hedging price risk on U.S. exchanges a more viable option.

\section{REFERENCES}

The word "processed" describes informally reproduced works that may not be commonly available through library systems.

Afzal, Mohammad, Abdus Salam, Mohammad Iftichas, Ahmed Khan, and Mohammad Ashiq. 1993. "Support Pricing Structure in Pakistan." Pakistan Journal of Agricultural Economics 2:68-97. 
Akiyama, Takamasa, and Panayotis Varangis. 1991. "Price Stabilization of Raw Jute in Bangladesh." Policy Research Working Paper 813. International Economics Department, World Bank, Washington, D.C. Processed.

Claessens, Stijn, and Jonathan R. Coleman. 1993. "Hedging Commodity Price Risks in Papua New Guinea." In Stijn Claessens and Ronald C. Duncan, eds., Managing Commodity Price Risk in Developing Countries. Baltimore, Md.: Johns Hopkins University Press.

Claessens, Stijn, and Ronald C. Duncan. 1993. "Overview." In Stijn Claessens and Ronald C. Duncan, eds., Managing Commodity Price Risk in Developing Countries. Baltimore, Md.: Johns Hopkins University Press.

Claessens, Stijn, and Panayotis Varangis. 1993. "Implementing Risk Management Strategies in Costa Rica's Coffee Sector." In Stijn Claessens and Ronald C. Duncan, eds., Managing Commodity Price Risk in Developing Countries. Baltimore, Md.: Johns Hopkins University Press.

- 1994. "Oil Price Instability, Hedging, and Oil Stabilization Fund. The Case of Venezuela.” Working Paper 1290. Policy Research Department, World Bank, Washington, D.C. Processed.

Coleman, Jonathan R., and Donald F. Larson. 1993. "Tariff-Based Stabilization of Commodity Prices in Venezuela." In Stijn Claessens and Ronald C. Duncan, eds., Managing Commodity Price Risk in Developing Countries. Baltimore, Md.: Johns Hopkins University Press.

Deaton, A. S. 1992. "Commodity Prices, Stabilization, and Growth in Africa." Discussion Paper 166. Research Program in Development Studies, Woodrow Wilson School, Princeton University, Princeton, N.J. Processed.

Ederington, Louis H. 1979. "The Hedging Performance of the New Futures Markets." Journal of Finance 34(1):157-70.

Faruqee, Rashid, and Jonathan R. Coleman. 1996. Managing Price Risk in the Pakistan Wheat Markets. World Bank Discussion Paper 334. Washington, D.C.: World Bank.

Gilbert, C. L. 1993. “Domestic Price Stabilization Schemes for Developing Countries.” In Stijn Claessens and Ronald C. Duncan, eds., Managing Commodity Price Risk in Developing Countries. Baltimore, Md.: Johns Hopkins University Press.

International Wheat Council. Various issues. World Wheat Statistics. London.

Knudsen, Odin, and John Nash. 1990. "Domestic Price Stabilization Schemes in Developing Countries." Economic Development and Cultural Change 38(April):539-58.

Larson, Donald F. 1993. "Policies for Coping with Price Uncertainty for Mexican Wheat." Policy Research Working Paper 1120. International Economics Department, World Bank, Washington, D.C. Processed.

Massell, B. F. 1969. "Price Stabilization and Welfare." Quarterly Journal of Economics 83(May):285-98.

Myers, Robert. 1993. "Strategies for Managing Coffee Price Risks in Costa Rica." In Stijn Claessens and Ronald C. Duncan, eds., Managing Commodity Price Risk in Developing Countries. Baltimore, Md.: Johns Hopkins University Press.

Newbery, D. M. G., and Joseph E. Stiglitz. 1981. The Theory of Commodity Price Stabilization. Oxford: Clarendon University Press.

Pakistan, Governmerit of. 1995. Economic Survey 1994-95. Islamabad: Finance Division, Economic Adviser's Wing. 
Palaskas, Theo, and Panayotis Varangis. 1991. "Is There Excess Co-Movement of Primary Commodity Prices? A Co-Integration Test." Policy Research Working Paper 758. International Economics Department, World Bank, Washington, D.C. Processed.

Satyanarayan, Sudaka, Maurice E. Thigpen, and Panayotis Varangis. 1993. "Hedging Cotton Price Risk in Francophone African Countries." Policy Research Working Paper 1233. International Economics Department, World Bank, Washington, D.C. Processed.

Sheales, T. C., and W. G. Tomek. 1987. "Hedging Australian Wheat Exports Using Futures Markets." Journal of Futures Markets 7(5):519-33.

Thomas, Vinod. 1985. Linking Macroeconomic and Agricultural Policies for Adjustment and Growth: The Colombian Experience. Baltimore, Md.: Johns Hopkins University Press.

U.S. Department of Agriculture. Various issues. Wheat: Situation and Outlook. Washington, D.C.: Economic Research Service.

Varangis, Panayotis. 1994. "Recent Developments in Agricultural Markets in Developing Countries." Paper presented at the Summit on Risk Management in American Agriculture, Farm Foundation and Commodity Futures Trading Commission, November 29, Washington, D.C. Processed.

Varangis, Panayotis, and Donald F. Larson. 1996. "Dealing with Commodity Price Uncertainty." Policy Research Working Paper 1667. International Economics Department, World Bank, Washington, D.C. Processed.

Varangis, Panayotis, Maurice E. Thigpen, and Takamasa Akiyama. 1993. "Risk Management Prospects for Egyptian Cotton.” Policy Research Working Paper 1077. International Economics Department, World Bank, Washington, D.C. Processed.

World Bank. 1994. "Pakistan: Strategy for Sustainable Agricultural Growth.” Gray Cover Report 13092-Pak. South Asia Region 1, Washington, D.C. Processed. 